\title{
MLL/AFF3 Fusion Gene
}

National Cancer Institute

\section{Source}

National Cancer Institute. MLL/AFF3 Fusion Gene. NCI Thesaurus. Code C99341.

A fusion gene that results from a chromosomal translocation $t(2 ; 11)(p 15 ; q 23)$ which fuses the $5^{\prime}$ half of the MLL gene to the 3 ' half of the AFF3 gene. This rearrangement is associated with acute lymphocytic leukemia and other leukemia types. 